ELOHI

Peuples indigènes et environnement

5-6 | 2014

Ressources du vivant

\title{
River Notes from the Montana Flathead Reservation: An Update on the "Ecological Indian"
}

Yves-Charles Grandjeat

\section{CpenEdition}

Journals

\section{Electronic version}

URL: http://journals.openedition.org/elohi/818

DOI: 10.4000/elohi.818

ISSN: 2268-5243

\section{Publisher}

Presses universitaires de Bordeaux

\section{Printed version}

Date of publication: 1 January 2014

Number of pages: 231-251

ISBN: 979-10-300-0021-4

ISSN: 2431-8175

\section{Electronic reference}

Yves-Charles Grandjeat, « River Notes from the Montana Flathead Reservation: An Update on the "Ecological Indian" », ELOHI [Online], 5-6 | 2014, Online since 01 January 2015, connection on 20 April 2019. URL : http://journals.openedition.org/elohi/818; DOI : 10.4000/elohi.818 


\section{River Notes from the Montana Flathead Reservation: An Update on the "Ecological Indian"}

\section{The Earth Is Full and Water Is Getting Scarce}

"The Earth is full. We are now using so many resources and putting out so much waste into the Earth that we have reached some kind of limit, given current technologies. The economy is going to have to get smaller in terms of physical impact," Paul Gilding writes in a recent book entitled The Great Disruption: Why the Climate Crisis Will Bring On the End of Shopping and the Birth of a New World. To back this up, Gilding mentions the designation, each year, by the NGO Global Footprint Network, of "Earth Overshoot Day", "the day when humanity officially exhausts nature's budget for the year", as the organization Earth Day Network puts it': "From this day forward, the planet will be operating under an ecological deficit, using more resources than the planet can produce". In 2013, Earth Overshoot Day came on Aug 20. In 2003, it came on Sept 22; in 1993, on Oct 10. According to the Global Footprint Network, our current rate of global consumption requires the resources of 1.5 Earths and will use up the resources of two Earths a year before mid-century if this rate is maintained. There is enough in those figures, as well as in the 2013 report recently released by the IPCC-the Intergovernmental Panel on Climate Change-(in French, the GIEC) to raise alarming questions about the consequences of the way in which mankind has been digging into the world's resources and about what it

1. http://www.earthday.org/blog/2013/08/20/earth-overshoot-day-2013. Consulted on Oct 5, 2013. 
will take-other than a final ecological apocalypse-for our economy "to get smaller in terms of physical impact".

In addition to oil, recently brought back to the foreground by the various fights generated by the Keystone Pipeline project, one resource that has most increasingly come to the fore of public attention lately in the U.S., notably the U.S. West, has been water. Reservoir and stream waters there have fallen to worryingly low levels, due to a combination of short supply (drought) and increasing demands from an expanding population used to unlimited consumption. In March 16 of this year (2014), for instance, a New York Times paper by Michael Wines entitled "West's Drought and Growth Intensify Conflict Over Water Rights" typically noted that "Across the parched American West, the long drought has set off a series of fierce legal and political battles over who controls an increasingly invaluable treasure-water."2 In the state of Montana, too, decreasing water supplies have raised alarm, notably because of shrinking snowcaps due to global warming-last year, for instance, the Bitterroot snowpack was $24 \%$ below its average level, and the Wyoming snowpack in general was down to $50 \%$ of normal. Although the focus of public concern has been on the States of Texas, Nevada, Colorado, Arizona, and California, this paper will focus on water management in the State of Montana, and the way in which Native tribal governments have been involved there in the water battles. The general purpose of this paper, indeed, as it brings back Native tribes into a picture from which they are sometimes strangely-and wrongly-excluded, is to argue that yes, notwithstanding scholarly arguments for or against the "Ecological Indian", Native American tribes in Montana have consistently shown an ecological concern in their treatment of this most precious natural resource-water, and that their deepest cultural legacy has always encouraged them to do so.

My (not very original) argument, backed up by readings of a few exemplary literary works, is that such Native American ecological behavior is deeply rooted in a cultural worldview central to the identities constructed in these novels, and further, out of the fictional world. This worldview practically encourages a relation to natural resources that meets de facto with ecological principles. These practices are derived from a spiritual element which is not necessarily present in the ecological approach-at least not in the scientific approach to ecology, although it does meet with some of the practices favored by deep

2. Michael Wines, “West's Drought and Growth Intensify Conflict Over Water Rights", The New York Times, March 16, 2014.

3. Lee Schweninger provides a most useful summary of the controversy in his introductory chapter "An Ethical Regard for the Land" (Schweninger, 1-15), with references to Sam Gill's Mother Earth and Shepard Krech's The Ecological Indian. 
ecology. My claim is that, as a matter of cultural principle, Native American approach to and management of natural resources does meet with ecological concerns. Of course, the historical process of European colonization of North America has at least strongly skewed any Native cultural principle, and powerfully distorted manifestations of such principles, so that any discussion of what a 'true' Native American approach to land use is helplessly caught in historical twists. The expropriation of Native tribes also destroyed land use practices that testified to a cultural and spiritual commitment to the land. Additionally, it stripped tribes of the rights to manage natural resources on the scarce territories that were allotted to them by treaty-and Montana is, again, a good case in point. Yet, the situation in Montana today also suggests that Native tribes have shown much cultural and political resilience. Their struggles to regain sovereignty rights over management of natural resources can also be viewed as environmental struggles. Their resistance to the historical process of dispossession and acculturation confirms that there are significant ideological and political convergences between Native American sovereignty struggles, on the one hand, and environmental battles, on the other. Ultimately, this paper wishes to argue that, from a scholarly perspective, and from a political activist point of view, these convergences should be acknowledged, and encouraged.

For non-Native Americans in Montana, management of water is a technical and an ecological problem; from a Native American perspective, it is both a political and a cultural issue. Water-as well as land-ties together ecological and sovereignty issues. In the State of Montana, Native people's water rights on the Flathead reservation date back to the 1855 Hellgate Treaty establishing the Flathead reservation and ensuring Native Americans, among other guarantees, "The exclusive right of taking fish in all the streams running through or bordering the said reservation" ${ }^{4}$, and this due to an aboriginal land right dating back to "time immemorial". This gives the local Salish, Kootenai and Pend d'Oreille tribes, gathered under the Confederated Salish and Kootenai Tribes (CSKT), a strong legal basis to validate any claim in litigation over water rights. And litigation has indeed run strong as part of a complicated, long-drawn battle to get the Montana State legislature to approve a Water Rights Compact worked out by the CSKT, the State of Montana, and the U.S. federal government, after ten years of hard negotiations. The purpose of this paper is not to provide a review of the legal battle. It is to suggest that beyond and behind legal arguments, what is at stake is a cultural relation to water. On the one hand, we find a Native ethos of respect for "resources" perceived as spiritual entities as well as material assets, in the context of a collaborative,

4. www.cskt.org/documents/gov/helgatetreaty.pdf 
integrated worldview. On the other, we have a utilitarian approach to natural resources perceived as expendable commodities-the approach which has led our Western model of relation to the land to the brink of ecological disaster. Native American works of literature, to the extent that we may assume that these works do reflect, to a significant degree, a collective cultural worldview, do back up the idea that respect for water is one of the most sacred principles of the Native ethos.

I will limit my all too brief incursion into Native American cultures to a reading of three literary works, by three authors writing at different times and from different tribal traditions, and to recent material produced by the Confederated Salish and Kootenai Tribes' Conservation and Natural Resources department. I am aware that this does not provide a strong basis for generalization and so the scope of my argument is limited, yet I am hoping that there is enough material here to point to significant entanglements and connections to offer an update of sorts to the debate on the ecological Indian. Methodologically, I am keeping in mind that a novel is a literary construction, not the direct expression of a collective culture; I am also aware that the "collective culture" is not a unified, frozen artefact, but a dynamic field of evolving forces. The three novels have been selected because they are part of a broad body of Native works largely centred on the protagonists' relation to water, often involving a struggle against a dam ${ }^{5}$. My contention is that these works are significantly grounded on specific cultures, including in terms of the environmental worldview they project and, so, that they do provide insight into tribal representations of water. As Paula Gunn Allen put it, "The significance of a literature can best be understood in terms of the culture from which it springs, and the purpose of literature is clear only when the reader understands and accepts the assumptions on which the literature is based" (Gunn Allen, in Glotfelty \& al 241). As for the remarkable material-brochures, books, DVD's-produced by the people working in the CSKT's Natural Resources and Conservation Department, it suggests that the Native American view of water as a sacred resource, to be honoured and respected, as we find it in the novels, is not just a literary construction, or a romantic fantasy born from or encouraged by a Western discontent with modernity, but a contemporary Native reality, which translates into hard fought political struggles. Recent struggles around water rights, in which Native American sovereignty questions are intricately tied up with environmental concerns, indeed illustrate

5. Louis Owens' Wolf Song would also feature prominently in this body of works, but works by non-Native writers, notably Edward Abbey, also come to mind. In addition to Silko's Ceremony, this paper will look very briefly at Hogan's Solar Storms to put McNickle's Wind from an Enemy Sky in a broader context. 
the extent to which an analysis of water issues calls for an integrated approach, in which cultural, legal and political factors must be woven together ${ }^{6}$.

\section{A literary expression of a Native American environmental ethos}

There are many instances in Native American literature that suggest that the American Indian view of natural resources meets with environmental principles, and Lee Schweninger has studied the material to an extent which can hardly be improved on ${ }^{7}$. From a Native American cultural perspective, of course, one has to use the notion of 'resource' with caution, and release it from a discourse in which nature is commodified at the exclusive service of human economy, industry and technology. The term "resource" should be broadened to a non-strictly utilitarian perspective, to include psychological, cultural, spiritual considerations as well. This re-definition of the term should also involve a reciprocal relation: humans preserve the health of nature which preserves the health of humans-i.e. physical, mental, spiritual, individual and collective health. Reciprocity here is a key notion, which is central to the Native ethos, in contrast with Western philosophical constructions of an environmental ethic, and with some expressions of deep ecology ${ }^{8}$.

In the reciprocal perspective at the heart of the Native ethos, nature can only be a resource to humans as long as humans also act as resources for nature. The fact of ecological inter-dependence is then translated, in the realm of conscious activity, into a sense of belonging to a community structured through ritual practices by means of which humans give to nature as much as nature gives to them. Indeed, reciprocity materializes as a give-and-take process in a symbolic

6. I would like to express my gratefulness and respect for the work and dedication of Germaine White, Thompson Smith, Roy Bigcrane and David Rockwell's, their generous sharing of their time and material when I was in Montana in June 2013. None of this would have happened without the enlightened guidance of my friend and colleague David Moore, from the University of Montana in Missoula.

7. Lee Schweninger's insightful review does not include Silko's Ceremony but David Moore's recent That Dream Shall Have a Name: Native Americans Rewriting America (University of Nebraska Press) convincingly invites Silko into an analysis of the intricate interweaving of sovereignty, community and identity (and irony, but not in Silko) in Native American literatures.

8. Here, I am wary of attacks on deep ecology as a manifestation of non-humanism. In deep ecology, rejection of humanism is really a rejection of anthropocentrism. Humanism is rejected to the extent that it is a form of anthropocentrism, while deep ecology advocates a belief in bio-equalitarianism. Yet what is present in Native American ethos, and not in bio-equalitarianism, is the idea of a spiritual connection between human and non-human forms of the living. 
exchange system. The strength of the human community rests on an awareness of its being part of a broader "biotic community", to borrow Aldo Leopold's phrase, with an ethical commitment to the right of each member of the biotic community to live and thrive. Every transgression of this ethos calls for some form of compensation. Again, in this ethos, symbolic acts are as real, if not more, than material ones. Humans and non-humans are not just perceived to interact on a biological, physical, chemical plane, but also enter into imaginary conversations and ceremonial interactions recognizing their equal partnership in the web of energy exchanges. Ceremonies, as Paula Gunn Allen writes, serve this integrative and strengthening purpose in ever widening circles: "The purpose of a ceremony is to integrate: to fuse the individual with his or her fellows, the community of people with that of the other kingdoms, and this larger communal group with the worlds beyond this one" (in Glotfelty \& al, 249). In this perspective, then, the term "resource" is not the most adequate. Silko's preference for the word "ally" comes to mind: "you know that simply to survive is a great triumph, that every possible resource is needed, every ally-even the most humble insect or reptile" (in Glotfelty \& al, 275). The connection with allies is activated in story-telling which, in Native American cultural traditions, is central to any ceremony. Leslie Marmon Silko's Ceremony (1977) is a case in point, to the extent that the narrative itself performs the sort of healing ceremony which it narrates.

Indeed, in Ceremony, Silko's narrative, telling the story of Tayo, a psychologically wounded Native World War Two veteran, returning to a native land parched by drought and scarred by nuclear tests, narrates and enacts a healing ceremony. There, the recovery of physical, psychological and spiritual integrity is individual and collective, in the broadest sense of the term, since this collective is enlarged from the individual to the tribal to the human to the earthly dimension of the planet. Water acts as a symbolic indicator of health or disease and Tayo's psychic healing eventually comes together with the healing brought by rain to the parched land.

Tayo used to stand in the big sandstone cave and hold the siphon hose under the water in the shallow pool where the spring water splashed down from the west wall of the cave. [...] "You see," Josiah had said, with the sound of the water trickling out of the hose into the empty wooden barrel, "There are some things worth more than money." (45)

In Silko's narrative, water is, again and again, acknowledged as the invaluable, sacred yet fragile source of collective life. Violence is materialized as drought, a symptom, in the Pueblo worldview, of a breach in the delicate balance of the world: "The old people used to say that droughts happen when people forget, when people misbehave" (46). Pueblo mythology, as Silko weaves it into her narrative, provides many stories explaining why water fails, and each is a tale 
of conflict, bringing havoc to the earth. Lack of water is testimony to a more general break in harmony, including on a social level:

And there was no more rain then.

Everything dried up

All the plants

the corn

the beans

they all dried up

and started blowing away

in the wind.

The people and the animals

Were thirsty.

They were starving. (13-14)

The most fundamental form of violence, in Ceremony, comes as a consequence of the way European culture has used science as a means to wreak unprecedented violence on mankind and on all living forms -a violence culminating with the digging for uranium, then the building and dropping of the atomic bomb. Lethal technology has been developed at the expense of the earth, from which lethal ore has been mined, with lethal consequences on local populations. For Silko, the destructive process is aimed simultaneously at the Earth, at Native tribes, and at the human race in general. What it testifies to is a deadly mindset born from a specific culture: European material and cultural history has divorced man from an Earth which Europeans gradually started thinking of as dead matter, or worse, as a hostile entity, then went on devastating:

\section{When they look}

They see only objects.

The world is a dead thing to them

The trees and rivers are not alive

The mountains and stones are not alive.

The deer and bear are objects

They see no life. $(135)^{9}$

Silko's fable thus contrasts two visions of the earth and the life forms that flourish on it. The European one is materialistic, exploitative and destructive, and it is based on fear. The traditional Native American one is animistic, respectful and caring, based on understanding and respect. Silko does refrain from simplistic dichotomy as she inserts into her narrative traditional tales of Indians messing around with nature-Corn Woman curses Reed Woman,

9. Italics in the text. 
people start fooling around with magic and start neglecting the land, etc. So the novel projects no idealized image of a pristine American Indian ecological Eden. Yet, fundamentally, the contrast between Native American and European views and practices holds, and rests on collective psycho-cultural considerations. Silko's prototypical white man appears to be led to destroy the earth out of a divorce from the land that has brought about guilt, hatred and fear-what Simon Estok, in a recent (2009) and controversial ISLE paper, has identified as western ecophobia ${ }^{10}$. The same system of representation is at the heart of Linda Hogan's Solar Storms.

Linda Hogan's novel Solar Storms is indeed another powerful example of a fictional representation placing environmental concerns at the heart of the indigenous worldview. The narrative follows four female protagonists, from four generations, focusing on the youngest of the four-Angel, a young native woman who, after many years of troubled exile, returns to her native land, and her native people, to undergo a healing process from which she will emerge at one with herself and the world. As often in Native American literature, the narrative comes as a response to a collective, cultural and psychological trauma, embodied in a wounded character. Here as in Silko, the term "collective" has to be used in the broadest sense $\mathrm{e}^{11}$, since it includes the whole realm of the living-plants, animals, earth, water, as well as humans. Indeed, the ancestors respected life in all forms: "There once had been a covenant between animals and men [...]. They would care for one another. It was an agreement much like the one between land and water" (SS 35). Travelling North with her three kinswomen, Angel can retrieve a tradition in which all living forms are interconnected: "the stones, too, were alive, the stinging nettles, the snails of Fur Island, and the tree which folded its leaves when touched by human hands" (81). In stories, in songs, in dreams, she even gains access to the common language they all spoke: "the division between humans and animals was a false one. There were times, even recent times when they both spoke the same language" (85). Yet this recovery does not come easy. It must be fought for, against a legacy of destruction handed down by the European colonizers. Again, destruction is economic, political, social, cultural, psychological and environmental at the same time, and the process is best encapsulated by the effects of the dam building project which

10. "Ecophobia is an irrational and groundless hatred of the natural world, as present and subtle in our daily lives and literature as homophobia and racism and sexism", "it is about power and control, it is what makes looting and plundering of animal and non animal resources possible. Self-starvation and self-mutilation imply ecophobia no less than lynching implies racism." (Estok 208)

11. David Moore makes a similar potent argument regarding the word "community" in his This Dream Shall Have a Name. 
the four women resolve to fight: "they'd killed thousands of caribou and flooded land the people lived on and revered. Agents of the government insisted the people had no legal right to the land. [...] If the dam project continued, [...] a way of life would end in yet another act of displacement and betrayal" (58).

As in Ceremony, Western settlers and Native people are shown to harbour starkly opposed values and ways of relating to the land. The Native view is based on a sense of community, respect, empathy and reciprocity, with a spiritual connection, while the European one is based on separation, exploitation, ruthlessness and plundering. While the destructive process might be given a historical origin, that of European territorial and industrial expansion westward on the American continent- "Old man said it was in the train tracks that went through land and came out of the iron mines" (40)-, the deeper roots of the process, again, seem located in the invaders' psychology. The immigrants are thought to have believed that "the wilderness was full of demons. [...] They feared the voices of animals singing at night. [...] Bush called them the reverse people. [...] For us, hell was cleared forests and killed animals. But for them, hell was this world in all its plenitude" (SS 86). The symmetry in the sentence structure enhances the contrast between the two worldviews based on two ways of relating to the land. But even more than on land, these worldviews here come to clash on water. As in McNickle's Wind from an Enemy Sky (1978), as we shall see, the opposition crystallizes on the building of a dam. For Europeans, the incentive is not just economic, it is also psychological: the dam is part of a process aiming at controlling nature and imposing structure and order on an unruly element, water, as well as destroying the native people by annihilating their culture. Even more than land, indeed, water has "a wildness, a stubborn passion to remain out of their (the surveyors') sense of order" (SS 123). There again, water highlights an opposition between a European will to stability and order, and a Native readiness to welcome fluidity and transformation which, in Angel's case, is enhanced by femininity. In her native watery world, Angel finds a sense of identity and belonging- "I was water falling into a lake and these women were that lake"(55)—, she finds strength and motion-"I was swimming stronger than ever, [...] my arms moved through water easily" (174). Water is the transformative element which makes healing and rebirth possible, because it never stays the same: "the land on Fur Island, the water, would pull a person in, steal from them, change them, then it would spit them up transformed, like Jonah from the belly of the whale" (68). Despite the biblical allusion, here, water, as a symbolic element, highlights an opposition between an integrative, caring, animistic indigenous worldview and a separative, fearful, Western Christian one, which also brings Hogan's protagonist to environmental activism. 


\title{
Deep Ecology meets Native American environmental ethics
}

Silko's and Hogan's narrative arguments meet with theoretical arguments voiced by European ecocritics in their attempts to identify-and therefore, hopefully, correct-the material, psychological and cultural roots of our environmental crisis, notably in the emerging field of ecopsychology, which looks for the roots of environmental crisis not just in the fields of history, science, technology, economics, culture, but also in the realm of (collective) psychology. A few significant examples drawn from the established ecocritical syllabus may suffice here. Lynn White's famous and controversial 1967 essay on "The Historical Roots of our Ecological Crisis" is a case in point. It draws from both cultural and material history to locate these "roots" in "the victory of Christianity over paganism", which White calls "the greatest psychic revolution in the history of our culture" (in Glotfelty et al, 9), as it contributed to foster the belief that "no item in the physical creation had any purpose save to serve man's purpose." (9) The invention in the late seventh century $\mathrm{AD}$ of a new plough which, the historian writes, "attacked the land with such violence that cross-plowing was not needed" (8), fundamentally altered man's relation to the land, and paved the way for further attacks by "modern technology, with its ruthlessness toward nature" (8) White's choice of vocabulary, here - "attacked", "violence", "ruthlessness", is all but innocent; it suggests that the technological changes which propelled European culture towards modernity and paved the way for today's environmental crisis, as rooted in a worldview conveyed by Christianity, are fueled by a psychological rage born from an alienation from nature. This chimes in strongly with the argument made in Silko's novel:

\author{
They fear \\ They fear the world. \\ They destroy what they fear. \\ They fear themselves. \\ $[\ldots]$ \\ They will poison the water \\ [...] \\ They kill what they fear. $(136)^{12}$
}

This also chimes in with Linda Hogan's narrator, in Solar Storms, describing the small houses built by missionaries with windows small enough to block out "the threatening miles of frozen lake on one side of them and, on the other, the dense, dark forests with its wolves" (30). In both Silko and Hogan's narratives, white settlers are true heirs to William Bradford's terrorized pilgrims brooding in the face of what they perceived as a "most hideous and desolate wilderness".

12. Italics in the original. 
To Paul Shepard, one of the founders of the field of ecopsychology with his groundbreaking Nature and Madness, the western mind's appetite for dualities - mind vs. body, culture vs. nature-has fueled a separative process breeding "a kind of failure in some fundamental dimension of human existence, [...], a kind of madness" (in Roszack, 24). Such separation bred frustration, which bred anger, and aggression directed back, with a vengeance, towards the object of frustration, i.e. nature. Modern society encourages, Shepard writes, "a readiness to strike back at a natural world that we dimly perceive as having failed us" (35), because we have failed it. Chellis Glendilling, a clinical psychologist and environmentalist, also locates the origin of environmental violence in the traumatic human disconnection from "Mother Earth": "from the tendrils of earthly textures, from the rhythm of sun and moon, from the spirit of bears and trees, from the life force itself" (Glendinning in Roszak et al, 51). Conversely, Mary E. Gomes and Allen D. Kanner, in "The Rape of the Well-Maidens", typically argue that human ability to reinhabit the world requires a shift from what they call a "separative" model of the self to a "Self-in-relation" model. The relational model focuses on human interconnections yet could "easily be extended beyond the human realm to include an ecopsychological perspective" (Gomes in Roszak, 118). We find the same holistic view of a global connected community of life in Paula Gunn Allen's description of the American Indian worldview: "At base, every story, every song, every ceremony tells the Indian that each creature is part of a living whole and that all parts of that whole are related to one another by virtue of their participation in the whole being" (Allen, 247). Such holistic reconnecting is precisely what ceremony makes possible for Tayo in Silko's novel, or for Angel in Hogan's Solar Storms.

Such material suggests a strong convergence between a traditional Native American worldview as projected by literature, and claims made in the new western field of ecopsychology, and by western intellectuals-Aldo Leopold, Arne Naess, Paul Taylor, among others-who have structured the thinking of deep ecology and the field of environmental ethics. One should of course quote Leopold's "land ethic", which "enlarges the boundaries of the community to include soils, waters, plants, and animals, or collectively: the land" (Leopold, 239). Naess' principle of "biospherical equalitarianism" (Naess, in Drengson \& Inoue, 4), or Taylor's biocentric argument that "from the perspective of a life-centered theory, we have prima facie moral obligations that are owed to wild plants and animals themselves as members of the Earth's biotic community. We are morally bound (other things being equal) to protect or promote their good for their sake" (Taylor, 198). 


\section{D'Arcy McNickle's Water Notes from the Mission Mountains}

One of the points made by critics of the "ecological Indian" thesis is that the stereotype of the ecological Indian is largely a western fiction, often encouraged by Native American informers' reading of the white anthropologist's and white environmentalist's expectations to egg them on. Literature may come into play here again as a rebuttal since D'Arcy McNickle's posthumous novel Wind from an Enemy Sky ${ }^{13}$, which brings us to Montana, was published in 1978 but written at great length in the 1940s and 1950s, that is before environmentalism became a cause célèbre in the U.S. and elsewhere, and largely predating the emergence of deep ecology in the 1970s. McNickle's novel precisely chooses the relation to water as a means to link up the legal and political question of Native control of natural resources with cultural and spiritual identity. The story dramatizes the failed attempt by an Indian tribe, the Little Elk-a direct fictional representative of McNickle's own adoptive tribe, the Salish and Kootenai-to recover the "Feather Boy" medicine bundle which harbours their traditional spiritual identity and collective strength. Loss of the bundle to white reservation had triggered tribal divisions and left the tribe in a state of spiritual disarray. The sacred bundle ended up in an East Coast museum of Native American artefacts whose owner, a rich white engineer, had also been involved in the building of a dam on tribal territory. The latter diverted water from tribal lands to a reservoir meant to irrigate allotments taken from the tribe and given to white settlers. The story thus links up intimately the loss of tribal cultural and spiritual identity, the development of the white man's industrial exploitation of natural resources, and the loss of tribal sovereignty on native territories stolen by the federal government through legal manoeuvres and political violence.

It comes as no surprise then that the story should start with a scene in which Bull, an Indian chief defending tribal traditions, ineffectively shoots his rifle at the dam which has stopped the river-which defies Bull's understanding: "The water was there when the world began. What kind of fool would want to stop it!"(1) Stopping the water has brought devastation to the land: "The gravels and sands of its course had the look of bleached bones. So it was true, what his kinsmen had been telling him. They had killed the water" (2-3). It has also locked the people in dark, negative thoughts; indeed, the dam has drowned sacred grounds, which is felt to have sped up the spiritual demise of the tribe. Such desecration appears to Bull as an unthinkable yet deliberate act, aimed simultaneously at the environment and at the people whose cultural strength, precisely, was derived from a respectful and spiritual relation to the land: "A man and a

13. McNickle's novel is also the focus of David Moore's insights in his That Dream Shall Have a Name: Native Americans Rewriting America. 
woman fit to each other after they live together a long time-that is the way a stream fits itself to the earth. [...] Were the animals and the trees asked to give their consent to this death? (24). In this holistic view expressed at the time when Aldo Leopold started elaborating on his "land ethic" and "land community" (Leopold 240), McNikles projects a view of humans, rivers, the earth, animals and trees as vitally and intimately interconnected. Against this view, the white gospel of increased production through technical and industrial exploitation is shown to encourage white settlers to plunder, ruthlessly and recklessly tearing, destroying, then walking on: "These mountains, trees, streams, the earth and the grass, from which his people had learned the language of respect-all of it would pass into the hand of strangers, who would dig into it, chop it down, burn it up" (131). This idea finds an echo in Linda Hogan's Solar Storms, where settlers are portrayed as leaving behind them a wake of havoc, laying waste to one region before moving on to the next, "to what hadn't yet been destroyed, leaving their women and children behind, as if they too were used up animals" (28).

The novel offers little hope, even though McNickle himself, as a politician, was less pessimistic than the author of the novel. The bundle was left to rot in the museum and has turned into a moth-eaten heap of dusty rags. The well-intentioned mediators trying to build bridges between Indians and white people are defeated by a legacy of conflict and misunderstanding. In his introduction to the novel, Louis Owens convincingly stresses McNickle's insistence, here, on problems of translation and communication from one culture to another. Indeed, the novel repeatedly points out the failure of Indians and whites to find a common language to work together. This is not just a problem of incommensurable worlds. The possibility of a common language has been destroyed by repeated assaults, by the white man-the white government-on the value of language. The systematic use of lying, dissembling, deceit, the endless string of broken promises and broken treaties in its relation with tribes to whom "so much depended on a good understanding" (28) and "words always seemed important" (31) have stripped language of any meaning. What is left is the evidence of spoliation, military, legal and political violence depriving the Indians of their native territories, forcing them into smaller and smaller reservations, dividing the reservation lands into individual allotments, opening them up, notably the most fertile areas of the reservations, to white settlement, then, in the case of the Salish and Kootenai Flathead reservation, diverting water from tribal lands to white lots.

This well-known historical process of relentless expropriation, based, like the building of the dam, on historical record, is exposed at length and in detail in Chapter 23 of the novel. There, the character of Adam, the white engineer, understands how he was drawn into a national form of institutional 
"thievery" (191). Adam understands that diverting the water was the culmination of this process: "the law didn't authorize the President to divide the water as well as the land, but Congress-our Congress, you and I-decided to do just that" (192). Water flowing from mountains located on tribal territories was collected in dams to benefit white homesteaders. The thousands of acres on reservation land which were drowned out by the reservoirs were taken "without agreement of compensation of any kind [...] and, again, without benefit to the Indians" (193). McNickle's choice of having Adam, a white man, denounce this process, shows a will to avoid simplifications pitting all Indians against all white people. Yet, Adam's tragic failure to reverse the process or just to return the sacred bundle suggests that, in McNickle's view in this narrative ${ }^{14}$, there is no possible reconciling based on the reparation of the historical land theft, no prospect of enabling Native Americans to recover land sovereignty and control of the land's resources, no return to traditional cultural values advocating a holistic view of the land promoting environmental health.

\section{Practical political convergences}

In this respect, it might be said that history has proved McNickle's bleak assessment wrong, on two counts: new leaders building bridges between communities and cultures have emerged, and found common ground, on the one hand, while, on the other, the Salish and Kootenai have found ways to defend, preserve, and in some cases win back control of natural, economic and spiritual resources. To put the CSKT's environmental activism in perspective, it may be worth to keep in mind the larger context of indigenous environmental activism. Political convergence of Native American and non-Native environmental activism in general has indeed been on the rise, activated by recent battles. The "Mountain Walk" a six-day pilgrimage taking a group of "Blackfeet Women against Fracking" from Chief Mountain to the Heart Butte Summit, two sacred sites on the Blackfeet reservation, to protest environmental harm caused by widespread hydraulic fracturing on the Blackfeet tribal territory, drew support from non-Native environmental NGOs such as the Montana Wilderness Association. It brought journalist Tristan Scott, from The Missoulian daily paper to report, "Opponents of the development worry that if the exploration continues unchecked, the hydraulically fractured oil wells and flare stacks could contami-

14. The novel does not sum up the whole of McNickle's thinking on the possibility of political reform towards the recovery of Native American sovereignty. His Native American Tribalism: Indian Survivals and Renewals offers a more positive prospect. See D. Moore, 82-83. 
nate a pristine ecosystem and disturb centuries-old cultural sites."15 The intersection of environmental-"contaminate a pristine ecosystem" — and cultural—“disturb centuries old cultural site"-concerns is characteristic of other recent cases of Native American involvement in environmental causes. One could mention Lakota chief Arvol Looking Horse's speaking out, in May 2013, against the XL Keystone pipeline as "the biggest cancer that is spreading upon Mother Earth caused by the tar sand efforts with the XL pipeline that is threatening to come through our territory and our sacred sites." ${ }^{16}$ Opposition to the so-called "megaload" shipments of gigantic oilfield equipment headed for the Canadian tar sand fields along the Lochsa and Clearwater rivers has come both from Nez Perce tribal and non-Native environmental activists, with Nez Perce activists vowing to "rid their reservation and ancestral homeland of the ravages of tar sand and industrial equipment and the resulting ecological, social and climate devastation." ${ }^{17}$ The same sort of alliance has seen Havasupai elders meeting with Sierra Club national executives and a feminist collective known as the "Mama Bears Brigade" to protest the reopening of a uranium mine at Red Butte, not far from Grand Canyon, or Apaches denouncing a copper mine project adjacent to tribal lands threatening the local water supply, etc. Of course there are divided stances within given tribes in the face of current environmental issues, and divided stances from one tribe to the other. A look at conflicting tribal responses to hydraulic fracking on the Blackfeet reservation is enough to deter any observer from simplistic statements. Yet, joint activism does point to possible convergences, as does the history of the CSKT tribal environmental activism.

\section{The CSKT, environmental ethics, and political activism}

In many respects, McNickle's novel showed the extent to which environmental and political questions, or issues of conservation and sovereignty, were inseparable on and around tribal lands and it may be argued that they still are. Historical involvement of the CSKT tribal government in conservation policies, notably as regards water, has been persistent and determined. More generally, the tribal government's Natural Resources Department, established in 1982 as part of the tribal Division of Fish, Wildlife, Recreation, and Conservation, has been active on many different fronts to achieve "good stewardship" of natural

15. Italics mine.

16. Internet site "Censored News", "Chief Arvol Looking Horse's Message May 2013", http://bsnorrell.blogspot.fr/2013/05/chief-arvol-looking-horses-message-may.html, consulted Sept.10, 2013.

17. http://wildidahorisingtide.org/2013/08/07/omega-loads-no-more-again/, consulted on Sept 10, 2013. 
resources" and "protect and enhance the fish, wildlife and wild land resources of the tribes for continued use by the generations of today and tomorrow,"18 as its mission statement puts it. In every case, sovereignty issues were tied in with environmental battles. This was the case in a high-profile legal battle as a result of which the tribe managed to regain, by contract from the federal government, and despite heavy opposition from the local Montana Fish and Wildlife officials, co-management of the National Bison Range on the reservation. Needless to point out, the bison is both a highly sensitive ecological and cultural iconic species, not only to Native Americans-and there are enough controversies today about the effects of bison reintroduction in Montana to confirm this. Another victory came in 1995 when, after a previous 20-year lease expired, the tribe forced oil giants Conoco, Exxon and Union Oil of California to shut down the 21 miles of their 550-mileYellowstone Pipeline running across tribal lands, on account of it being too dangerous: there had been numerous leaks, including three major spills, involving serious environmental damage to tribal lands, during the previous lease. In 1998, the tribe won $\$ 18.3$ million from The Atlantic Richfield Company (ARCO) to restore, replace, and/or acquire the equivalent of Tribal treaty protected resources that were injured by the release of hazardous substances in the Clark Fork River, through mining and smelting in Butte and Anaconda. Additionally, over the past 40 years, the CSKT have successfully fought back several attempts by utility companies to build dams on reservation lands, similar to Kerr Dam, which was built on the Flathead River from 1936 to 1938 by the Montana Power Company and provided inspiration for McNickle's novel. Actually, in 1984, the tribe successfully negotiated re-licensing of Kerr Dam, raising the fee from $\$ 2.6$ million to $\$ 9$ million annually, along with annual adjustments for inflation and, more importantly, securing the option to take control of the dam next year, in 2015. Clearly, each of these battles was at the same time and inseparably an environmental battle and a sovereignty battle, fought through hard legal litigation, and often, one should add, with the support of federal agencies against resistance by local authorities.

\section{Water Notes from the Mission Mountains}

The devastating impact of the dam on tribal social, economic and cultural life was fully documented by Roy Bigcrane and Thompson Smith's 1991 film The Place of Falling Waters. The film shows how the building of the dam was a tipping point in a systematic, relentless process of economic, social and cultural destruction of the tribe. People who had always made a living from a reciprocal,

18. http://www.cskt.org/tr/fwrc.htm, consulted Oct 16, 2013. 
respectful, collective relation to water and the land, were turned into individual wage-earners forced to buy the food they could no longer get from the land with wages earned as a labor force for a capitalistic company using and abusing water as raw material for profit. History also shows, however, that CSKT Indians, succeeded in resisting the process of cultural eradication. The very production of Bigcrane and Smith's film is evidence of such resistance. Recent filmed material, including the interactive DVDs Explore the River and Lower Flathead River produced by the CSKT's Natural Resource Department in preparation for the tribe's annual River Honoring event, is added evidence of such resilience. Explore the River features many interviews of tribal elders, notably the opening words of Toni Incashola, director of the Salish and Pend d'Oreille Cultural Committee and Vernon Finley, from the Kootenai Cultural Committee, stressing the spiritual value of the river-which the dam was precisely aimed at destroying: "the most spiritual connection that the old timers made were often in places along rivers", Vernon Finley recalls. The tribal elder recalls how "old-timers" viewed travelling on the river not just as "a way of getting from one place to the other", but on a spiritual level, as a statement about "the way you carry yourself on this earth." Protecting the river is not just a conservation gesture, making sure one has "clear drinking water", for instance, but has to do with "the very spirit of who you are, your entire worldview", in connection with the whole of nature: "The old-timers were aware that everything out there, including the water, the rocks underneath the water, the trees, every different tree, every different type of grass, the wind itself, had songs, and each of us has the ability to hear those songs"(Explore the River). The holistic, spiritual view of the earth community is powerfully expressed here by tribal elders not as a belief of the past but as part of a tradition which is successfully handed down, and has been kept alive through consistent educational work and collective rituals such as the yearly River Honoring Festival held by the tribe.

On the other hand, recent events show how opposition to Indian sovereignty may block an environmental agenda. As mentioned earlier, on April 3, 2013, the Montana legislature, under pressure from Republican controlled House subcommittees, killed a bill aimed at ratifying the Water Rights Compact agreed on by the CSKT, the State of Montana, and the U.S. federal government after ten years of hard committee work. Even though the compact was approved by the State of Montana's Reserved Water Rights Compact Commission, whose job is, precisely, to ensure "the equitable division and apportionment of waters between the State and its people and the several Indian Tribes claiming reserved water rights within the state"19, opponents to the compact protested it would

19. http://www.dnrc.mt.gov/rwrcc/, consulted Oct 10, 2013. 
give the tribes too much control over water in Western Montana and would hurt non-Indian irrigators on the reservation. Part of the problem stems from the fact that, as a result of the 1908 Allotment Act, only 7,000 of the reservation's more than 28,000 residents-a definite minority-are American Indians. As a NYT article put it: "farmers and ranchers on the reservation fear they could lose half the water they need to grow wheat and hay and to water their cattle. ${ }^{20}$ Clearly, what is at stake here is a political, sovereignty issue as much as an environmental one, with organized white irrigators up in arms against the idea that a tribal government might have political authority over them and cap their use of natural resources. As put in legal terms, in an article in the Missoulian, these opponents claim that "Components of the proposed CSKT Compact involve the unconstitutional taking of property rights (water), $[\ldots]$ and place state citizens under the jurisdiction of a government within which they have no vote or representation." 21

While the complexity of this recent and still pending water battle far exceeds the scope of this paper (the water compact itself is a 1,200-page document), we have here yet another example of the problematic entanglement of conservation and sovereignty battles in and around tribal lands, suggesting that tribal conservation policies, and the environmental philosophy behind them, cannot materialize lest Native sovereignty rights are recognized. On the other hand, it also suggests that conservation policies will be pursued even more aggressively by tribal governments if they also carry sovereignty questions. Indeed, the example of the CSKT demonstrates there are cases when the tribal conservation agenda can be boosted because, in addition to being consistent with the tribal environmental ethos, it also gives the tribe a means to strengthen its political power and assert its sovereignty rights.

The material we have just reviewed suggests that the idea that Native American tribes may favour a concern for conservation, based on a determination to preserve a cultural heritage emphasizing a respectful approach to the land, is not a fantasy born from romantic western stereotypes of the ecological Indian. Native American literary works, as we have seen, sustain the argument of an intellectual convergence between traditional Native American worldviews and principles of deep ecology. Numerous recent examples of tribal activism suggest that respect for the land is at the vital heart of a collective culture which some Native American tribes, including the CSKT, have fought hard to preserve. Yet

20. "Water Rights Tear at an Indian Reservation", Jack Healy, The New York Times, April 21, 2013.

21. "Critics Suggest Alternative Water Compact for Flathead reservation", The Missoulian, July 21, 2013. http://missoulian.com/mobile/article_4b420054-f1b6-11e2-b33b0019bb2963f4.html, consulted Oct 16, 2013. 
it is also clear that tribal conservation battles are intricately intertwined with sovereignty battles, potentially arousing opposition from a significant fraction of non-Indian residents on and off the reservation. Those descendants of the white conquerors depicted in the novels we have read may challenge the tribal sovereignty rights over the territories parcelled out by the federal government, and refuse tribal control and management of natural resources on those territories. Meanwhile, white irrigators show little regard for local or global consequences of their water use (and, for some, abuse)—notably diminishing water levels in streams running from and through the reservation. Tribal sovereignty battles can thus be seen to foster broader, non-tribal environmental interests. Wouldn't it then seem fitting, in keeping with the principle of reciprocity, that those involved in environmental battles should direct a portion of their activism towards supporting Native Americans in their struggles for sovereignty?

\section{Works cited}

ALLEN, Paula Gunn. "The sacred Hoop." Glotfelty, Cheryll \& Harold Fromm, eds. The Ecocriticism Reader. Athens, Ga: University of Georgia Press, 1996. 241-263.

ESTOK, Simon C. "Theorizing in a Space of Ambivalence: Ecocriticism and Ecophobia”. ISLE 16.2. Oxford: Oxford Journals, Oxford University Press, 2009, 203-225.

GILDING, Paul. The Great Disruption: Why the Climate Crisis Will Bring On the End of Shopping and the Birth of a New World. London: Bloomsberry Press, 2012.

GILL, Sam. Mother Earth: An American Story. Chicago: University of Chicago Press, 1987.

GLENDILLING, Chellys. "Technology, Trauma and the Wild.” Roszak, Theodore, Gomes, Mary E. \& Allen D. Kanner, eds. Ecopsychology. Restoring the Earth, Healing the Mind. San Francisco: Sierra Club Books, 1995. 41-54.

GLOTFELTY, Cheryll \& Harold FROMM, eds. The Ecocriticism Reader. Athens, Ga.: University of Georgia Press, 1996.

GOMES, Mary E. \& Allen D. KANNER. "The Rape of the Well-Maidens: Feminist Psychology and the Environmental Crisis." Roszak, Theodore, Gomes, Mary E. \& Allen D., Kanner, eds. Ecopsychology. Restoring the Earth, Healing the Mind. San Francisco: Sierra Club Books, 1995. 111-121.

HOGAN, Linda. Solar Storms. New York: Scribner, 1995.

KRECH, Shephard. The Ecological Indian: Myth and History. New York: Norton, 1999.

LEOPOLD, Aldo. A Sand County Almanach. 1949. New York: Ballantine Books, 1970. 
MCNICKLE, D’Arcy. Wind From an Enemy Sky. 1978. Albuquerque, N. M.: University of New Mexico Press, 1988.

MOORE, David. That Dream Shall Have a Name: Native Americans Rewriting America. Lincoln and London: University of Nebraska Press, 2014.

ROSZAK, Theodore, Gomes, Mary E. \& Allen D. Kanner, eds. Ecopsychology. Restoring the Earth, Healing the Mind. San Francisco: Sierra Club Books, 1995.

SCOTT, Tristan. "Blackfeet Women make Pilgrimage to Call Attention to Hydraulic Fracturing on Native Land." The Missoulian, Aug 11, 2012.

SHAPIRO, Elan. "Restoring Habitats, Communities and Souls." Roszak, Theodore, Gomes, Mary E. \& Allen D. Kanner, eds. Ecopsychology. Restoring the Earth, Healing the Mind. San Francisco: Sierra Club Books, 1995. 224-239.

SHEPARD, Paul. "Nature and Madness." Roszak, Theodore, Gomes, Mary E. \& Allen D. Kanner, eds. Ecopsychology. Restoring the Earth, Healing the Mind. San Francisco: Sierra Club Books, 1995. 21-40.

SCHWENINGER, Lee. Listening to the Land. Athens, GA: The University of Georgia Press, 2008.

SILKO, Leslie Marmon. Ceremony. New York: Viking Penguin, 1977.

WHITE, Lynn. "The Historical roots of our ecological Crisis." Glotfelty, Cheryll \& Harold Fromm, eds. The Ecocriticism Reader. Athens, Ga.: University of Georgia Press, 1996. 3-14.

WINES, Michael. "West's Drought and Growth Intensify Conflict Over Water Rights." New York Times, March 16, 2014.

\section{Films}

Bigcrane, Roy \& Thompson Smith. The Place of the Falling Waters. SKT Media/public TV. Salish Kootenai College, Pablo, MT., 1991.

CSKT Natural Resource Department. Lower Flatheat River. An Interactive, Multimedia DVD and Explore the River, CSKT Natural resource Department, Pablo, MT. Date not mentioned.

\section{Internet sources (in order of appearance)}

http://www.earthday.org/blog/2013/08/20/earth-overshoot-day-2013 consulted on Oct 5, 2013.

www.cskt.org/documents/gov/helgatetreaty.pdf

http://bsnorrell.blogspot.fr/2013/05/chief-arvol-looking-horses-messagemay.html, consulted on Sept.10, 2013.

http://wildidahorisingtide.org/2013/08/07/omega-loads-no-more-again/, consulted on Sept 10, 2013.

http://www.cskt.org/tr/fwrc.htm, consulted Oct 16, 2013.

http://www.dnrc.mt.gov/rwrcc/, consulted Oct 10, 2013.

http://missoulian.com/mobile/article_4b420054-f1b6-11e2-b33b0019bb2963f4.html, consulted Oct 16, 2013. 
Résumé : Dans un contexte de crise environnementale qui plaide en faveur de modes de gestion des richesses planétaires plus économes et respectueux de « ressources » limitées, cet article s'intéresse à la relation à l'eau dans les cultures amérindiennes. S'appuyant sur des exemples tirés de la littérature, et sur plusieurs documents produits par le Bureau des Ressources Naturelles des Confederated Salish and Kootenai Tribes (CSKT) du nord du Montana, I'article dégage, à propos de représentations de l'eau, de profondes convergences entre la perception amérindienne de la nature et les principes de l'écologie profonde tels que les a formulés la philosophie occidentale après les années 1970. Notant de nombreux cas d'alliances entre militants écologistes non-amérindiens et Amérindiens militant pour le respect de leurs droits à la souveraineté territoriale et de leurs traditions culturelles ancestrales, l'article s'intéresse aux luttes menées par les Amérindiens des CSKT pour la gestion de l'eau, pour dépasser le débat sur le mythe de "l'indien écologique » et apprécier la convergence de fait entre luttes écologistes et luttes politiques amérindiennes.

Mots-clefs : Amérindiens, Écologie, Eau, Montana, CSKT.

Abstract: In a global context in which we hear repeated calls to change our relation to the environment and stop plundering resources that are running increasingly scarce, this article looks at the relation to water, and more generally, to the natural environment, found in traditional Native American cultures. Using examples from Native American literature as well as material produced by the Confederated Salish and Kootenai Tribes (CSKT) from the Flathead reservation in Northern Montana, this paper shows how Native representations of nature meet with the deep ecology movement as it has developed in the West. Looking at examples collaboration between non-Native environmental activists and Native activists fighting simultaneously for natural conservation, cultural preservation and political sovereignty, this paper invites readers to move beyond the debate on the "ecological Indian" as myth or reality, and to appreciate the de facto convergence of concerns for environmental preservation and for Native American political sovereignty.

Keywords: Native-Americans, Ecology, Water, Montana, CSKT

Yves-Charles Grandjeat est professeur de littérature américaine à l'université Bordeaux Montaigne, où il a dirigé plus de 15 ouvrages collectifs sur la littérature américaine contemporaine. Il a travaillé sur les littératures dites " ethniques», avec deux livres et de nombreux articles sur les cultures et littératures des Latinos aux États-Unis (dont Aztlan : terres volées, terre promise aux presses de l'ENS), puis sur la littérature afro-américaine (avec notamment un livre sur John Edgar Wideman, Le feu et la neige). Depuis quelques années il s'intéresse de près aux écrivains de la nature (Rick Bass, Wendell Berry, Annie Dillard, Aldo Leopold, Barry Lopez, Peter Matthiessen, Doug Peacock, Gary Snyder, Terry Tempest Williams) et ce qu'on appelle aujourd'hui, « l'écocritique».

Yves-Charles Grandjeat is a professor of American Literature and American Studies at the Bordeaux Montaigne university. He has edited or coedited over 15 volumes on contemporary American literature. His own research has first taken him to write and publish on Latino cultures in the U.S., notably Chicano and Chicana literatures with many papers and two books (including Aztlan : terres volées, terre promise published by the École Normale Supérieure presses). He has also contributed studies of Afro American literatures, with papers on a number of different authors and a book on John Edgar Wideman, Le feu et la neige. Recently, he has turned his interest to American nature writers and ecology, with papers on Rick Bass, Wendell Berry, Annie Dillard, Aldo Leopold, Barry Lopez, Peter Matthiessen, Doug Peacock, Gary Snyder, Terry Tempest Williams, and more generally, ecocriticism applied to literature. 
